\title{
Impact of location characteristics on renewable energy production for a group of buildings
}

\author{
Krystian Szczerbak ${ }^{1, *}$ \\ ${ }^{1}$ Wrocław University of Science and Technology, Faculty of Environmental Engineering, \\ Wybrzeże Wyspiańskiego 27, Wrocław 50-370, Poland
}

\begin{abstract}
The climate in Poland is slightly disparate in each region. The differences in temperature not always come along with the intensity of solar radiation in 5 climate zones. South of the country is colder, but well irradiated by the Sun and northern regions have milder climate, but are less irradiated. This fact alone makes people consider the suitability and safety of using renewable energy sources such as air-to-water heat pumps, solar collectors and photovoltaics instead of more traditional, fossil fuel powered sources. This paper presents a comparison analysis of energy demand and the cost for heating in a group of single-family buildings by 4 variants (gas boiler, gas boiler and solar collectors, air-to-water heat pump, air-to-water heat pump and photovoltaics) in 5 chosen cities in each polish climate zone. Calculations were done for space heating and domestic hot water energy demand, $\mathrm{CO} 2$ emissions and cumulative costs for all variants and locations. The results confirm the inconsistency of polish climate and have shown profitability and utility of renewable energy sources.
\end{abstract}

\section{Introduction}

The energy consumption is constantly rising, meaning the harmful effects of burning fossil fuels will also be more dangerous [1], as the current emissions level is already affecting environment and peoples heath strongly [2]. One of the main sources of $\mathrm{CO}_{2}$ and other pollution emissions are residential areas [3]. The implementation of new technologies and renewable energy and heat sources is desperately needed in Poland in order to decrease current emission level, but the application of renewable energy sources in Poland slowly grows every year. This fact is mostly determined by high investment cost in new energy sources and people awareness, that because of polish cold climate and solar irradiation weaker than in the southern countries, this type of powering will not be safe. By year 2009 residential buildings powered by heat pumps were $0.03 \%$ of all residential buildings in Poland [4]. Although the air-condition case for residential buildings has become more common [5] it is a very low percentage in Poland and was skipped in the analysis. In favour of renewable energy sources usage for heating is the indication, that harshness of climate in Poland goes together with bigger intensity of solar irradiation [6]. This paradox results from the geographical characteristic of polish climate. The mild climate

* Corresponding author: krystianszczerbak@gmail.com 
in the north is sustained by the impact of the Baltic Sea and small solar irradiation. On average solar irradiation is bigger in southern parts of Poland, but at the same time the ground level rises to the South, indicating colder temperatures. The main aim of this paper is to show performance of 3 variants of ecological heat source systems for a group of houses compared by emission and combined investment and maintenance cost to natural gas boiler heating system in all five climate zones in Poland. The results will show effectiveness and profitability of using renewable energy sources and the differences in efficiency of the same heating systems. depending on their location.

\section{Research methodology}

The analysed example consists of 100 buildings group with 4 variants of heat source for space heating and domain hot water, placed in different locations in Poland to show the influence of location on performance of chosen energy supply systems. Yearly temperatures and solar irradiation data for every hour were taken from official meteorological stations data published by Ministry of Investments and Development [6]. Building heat load, domain hot water heat and seasonal demanded heat were calculated for all heating system variants using polish norms: PN-B-02025:2001 [7], PN-EN 12831:2006 [8], PN-EN ISO 6946:2008 [9]. Heat pumps performance and heat production was calculated based on norm PN-EN 14825:2019-03 [10] and producer catalogues. Analysis of solar powered sources (solar collectors and photovoltaic panels) were calculated with simplified efficiency methods presented in Efficient Buildings with Solar and Geothermal Resources [3], which are accurate enough for an analysis based on statistic data [11]. Calculated performances were then converted to $\mathrm{CO}_{2}$ emission level [1] based on National Center for Emission Management (KOBiZE) data [12]. The financial analysis is carried out on the bases of Simple Payback Time (SPBT) factor [13].

\section{The characteristics of selected locations}

The main reason of selection was to show the inconsistence in Poland's balance of yearly temperatures and intensity of solar irradiation. Figure 1 shows the map of Poland's climate zones and the selected cities. Figure 2 shows the map of Poland's yearly sum of direct normal solar radiation and the selected cities. The highest values of solar energy occur in south-east part of Poland (Lublin), but similar values also occur in Zakopane where the temperature conditions are much harder, which made that region much more interesting for the study. Five cities have been chosen as a representatives of each climate zone in Poland:

Koszalin $\left(1^{\text {st }}\right.$ climate zone, $\left.-16^{\circ} \mathrm{C}, 950 \mathrm{kWh} / \mathrm{m}^{2}\right)$, North-West;

$>$ Wroclaw $\left(2^{\text {nd }}\right.$ climate zone $\left.-18^{\circ} \mathrm{C}, 1050 \mathrm{kWh} / \mathrm{m}^{2}\right) \mathrm{West}$;

$>$ Katowice $\left(3^{\text {rd }}\right.$ climate zone $\left.-20^{\circ} \mathrm{C}, 1050 \mathrm{kWh} / \mathrm{m}^{2}\right)$ South-West;

$>$ Olsztyn $\left(4^{\text {th }}\right.$ climate zone $\left.-22^{\circ} \mathrm{C}, 980 \mathrm{kWh} / \mathrm{m}^{2}\right)$ North-East;

$>$ Zakopane $\left(5^{\text {th }}\right.$ climate zone $\left.-24^{\circ} \mathrm{C}, 1100 \mathrm{kWh} / \mathrm{m}^{2}\right)$ South, Tatra Mountains. 


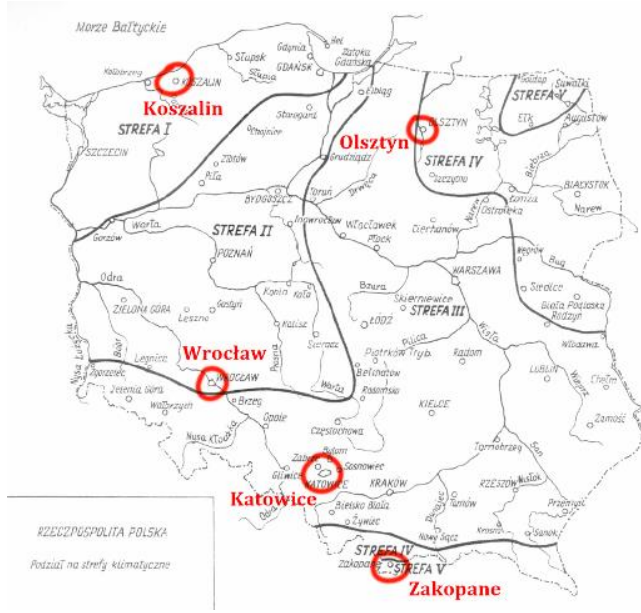

Fig. 1. Main 5 climate zones of Poland [8].

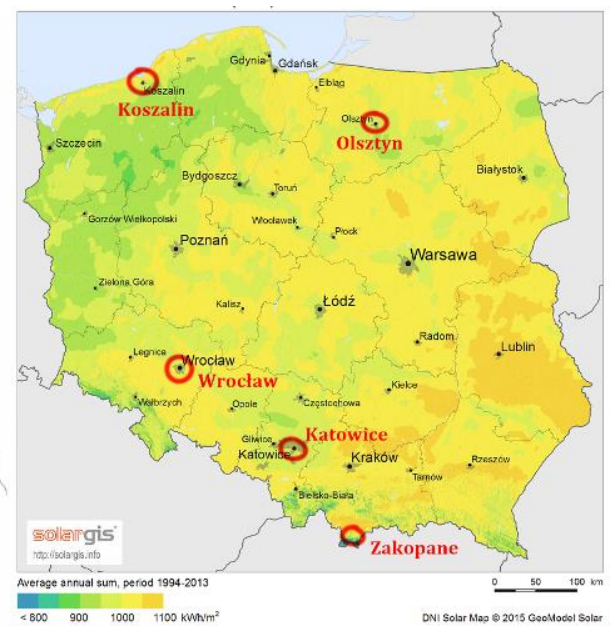

Fig. 2. Intensity of direct normal solar irradiation in Poland [14].

\section{Considerations of analysed buildings and systems}

The analysis provided for 100 new, single-family buildings, built on the base of low energy regulations for year 2017 [15], with standard water and temperature demands. Calculated heat load per building is $14.60 \mathrm{~kW}$ for external temperature of $-20^{\circ} \mathrm{C}$. Usable heating energy demand for buildings varies from 68 to $77 \mathrm{kWh} / \mathrm{m}^{2}$ a, depending on their location. As shown in figure 3 , in the analysis the following 4 variants of heat and energy supply systems were considered:

$>\mathrm{GB}$ - gas boiler - fossil fuel representative, standard and popular system;

$>\mathrm{GB}+\mathrm{SC}-$ gas boiler with solar collectors - slight ecological improvement, easy and cheap in implementation;

$>\mathrm{HP}$ - air-to-water heat pump more expensive system with no local emission, requires powering from power grid and causing more emissions from power plant;

$>\mathrm{HP}+\mathrm{PV}$ - air-to-water heat pump with photovoltaics - the most costly and ecological system with no local emission and low
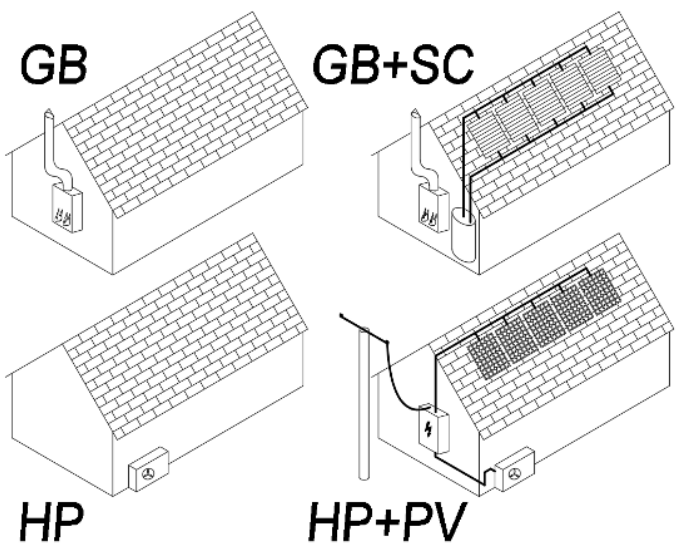

Fig. 3. Analysed variants of heat and energy supply systems. external power supply. 


\section{Comparison of energy consumption and emissions}

The calculated useful energy needed for buildings in analysed systems in every region is presented in table 1 . It is the sum of space heating and domain hot water energy demanded annually for buildings. The analysis included differences in heating period and actual outside air temperature for every hour in year for all studied locations.

Table 1. Results of heating energy calculations.

\begin{tabular}{|c|c|c|c|c|}
\hline City & Climate zone & $\begin{array}{c}\text { Lowest } \\
\text { temperature }\end{array}$ & $\begin{array}{c}\text { Average } \\
\text { temperature }\end{array}$ & Useful energy \\
\hline Koszalin & $1^{\text {st }}$ & $-16^{\circ} \mathrm{C}$ & $7.5^{\circ} \mathrm{C}$ & $1298540 \mathrm{kWh}$ \\
\hline Wroclaw & $2^{\text {nd }}$ & $-18^{\circ} \mathrm{C}$ & $8.2^{\circ} \mathrm{C}$ & $1308900 \mathrm{kWh}$ \\
\hline Katowice & $3^{\text {rd }}$ & $-20^{\circ} \mathrm{C}$ & $7.7^{\circ} \mathrm{C}$ & $1319300 \mathrm{kWh}$ \\
\hline Olsztyn & $4^{\text {th }}$ & $-22^{\circ} \mathrm{C}$ & $6.8^{\circ} \mathrm{C}$ & $1433500 \mathrm{kWh}$ \\
\hline Zakopane & $5^{\text {th }}$ & $-24^{\circ} \mathrm{C}$ & $5.0^{\circ} \mathrm{C}$ & $1568400 \mathrm{kWh}$ \\
\hline
\end{tabular}

Required useful energy was converted into final energy and emitted $\mathrm{CO}_{2}$ emission for every heat source system. Solar collectors and photovoltaic panels performance is noticeable low in winter, but from May to October the energy produced is high enough to cover local energy needs. Additionally the surplus of energy produced by photovoltaics in the summer is sent to energy network and can cover the energy needs in winter by lower costs than standard rates. Figures 4, 5, 6, 7 and 8 show the calculated emissions for all selected locations and energy sources.

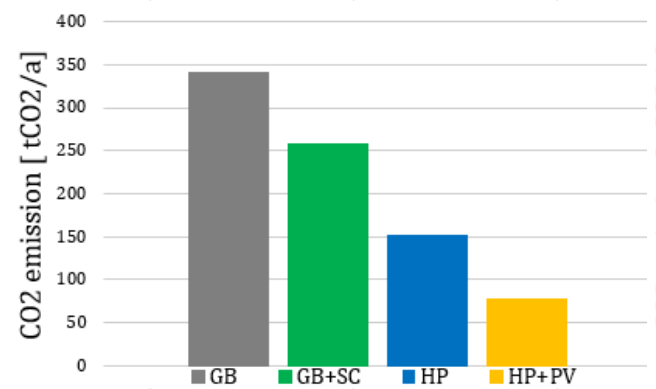

Fig. 4. Emissions by energy source in Koszalin ( $1^{\text {st }}$ climate zone).

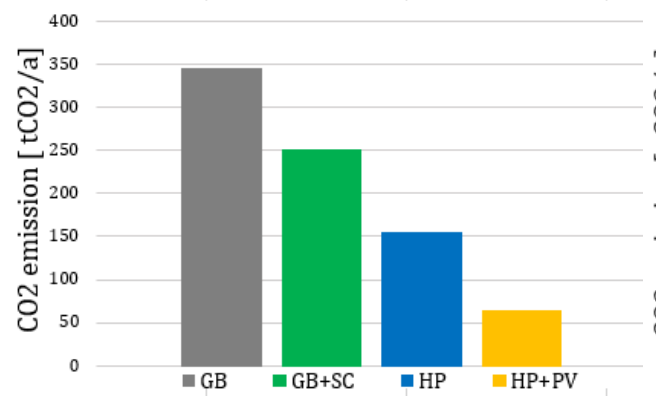

Fig. 6. Emissions by energy source in Katowice $\left(3^{\text {rd }}\right.$ climate zone).

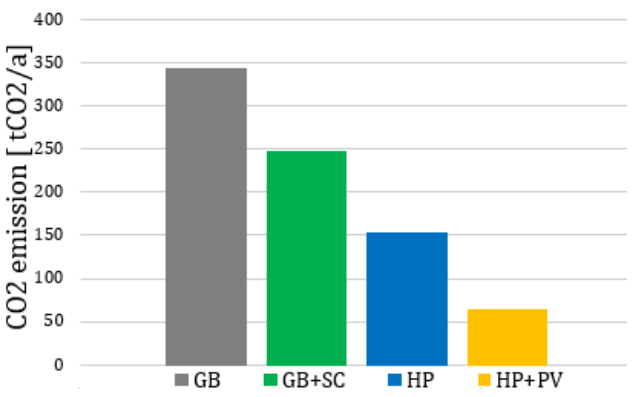

Fig. 5. Emissions by energy source in Wroclaw ( $2^{\text {nd }}$ climate zone).

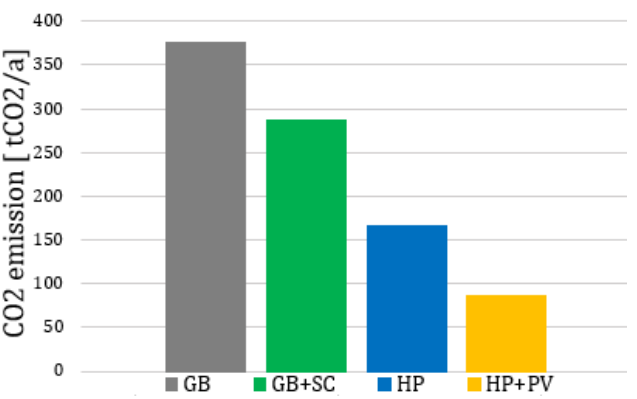

Fig. 7. Emissions by energy source in Olsztyn ( $4^{\text {th }}$ climate zone). 


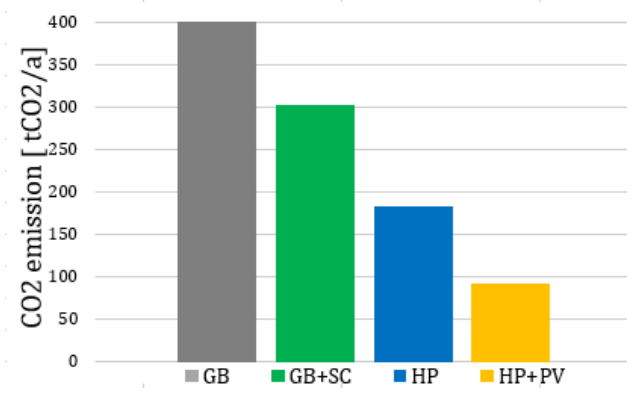

$\begin{array}{ll}\text { Koszalin: } & \begin{array}{l}\text { Heat pump COP: } 3.5 \\ \text { Solar energy share: } 22 \%\end{array} \\ \text { Wroclaw: } & \begin{array}{l}\text { Heat pump COP }=3.5 \\ \text { Solar energy share: } 25 \%\end{array} \\ \text { Katowice: } & \begin{array}{l}\text { Heat pump COP }=3.5 \\ \text { Solar energy share: } 25 \%\end{array} \\ \text { Olsztyn: } & \begin{array}{l}\text { Heat pump COP }=3.5 \\ \text { Solar energy share: } 21 \%\end{array} \\ \text { Zakopane: } & \begin{array}{l}\text { Heat pump COP }=3.5 \\ \text { Solar energy share: } 24 \%\end{array}\end{array}$

Fig. 8. Emissions by energy source in Zakopane $\left(5^{\text {th }}\right.$ climate zone $)$.

From the presented figures it emerges that the highest environmental effect occurs in the coldest region, Zakopane. It comes from two elements: high energy demand (low temperatures) and high solar irradiation. As it goes for all locations, the lower the temperatures and the higher the solar radiation, the better selected variants perform. The ratio of temperatures to solar radiation is variable. Air-to-water heat pumps COP factor is around 3.5 and outside air temperatures over the year are mostly balancing from 0 to $10^{\circ} \mathrm{C}$, what makes a stable and efficient work conditions in all analysed climate zones.

In terms of solar irradiation and performance of solar-powered energy sources the analysis has shown that Wroclaw, Katowice and Zakopane $\left(2^{\text {nd }}, 3^{\text {rd }}\right.$, and $5^{\text {th }}$ climate zones $)$ are the most suitable.

\section{SPBT analysis}

The systems were analysed over the period of 20 years, as during this time all variants should function without issues and major maintenance works. Figures 9, 10, 11, 12 and 13 shows the cumulative costs for all variants in all locations. Considered costs included all devices, heat and energy sources and installation investment costs and then fuel, power and maintenance costs during exploitation time [13]. For all types of renewable energy sources $30 \%$ of co-financing from external sources was included in calculations.

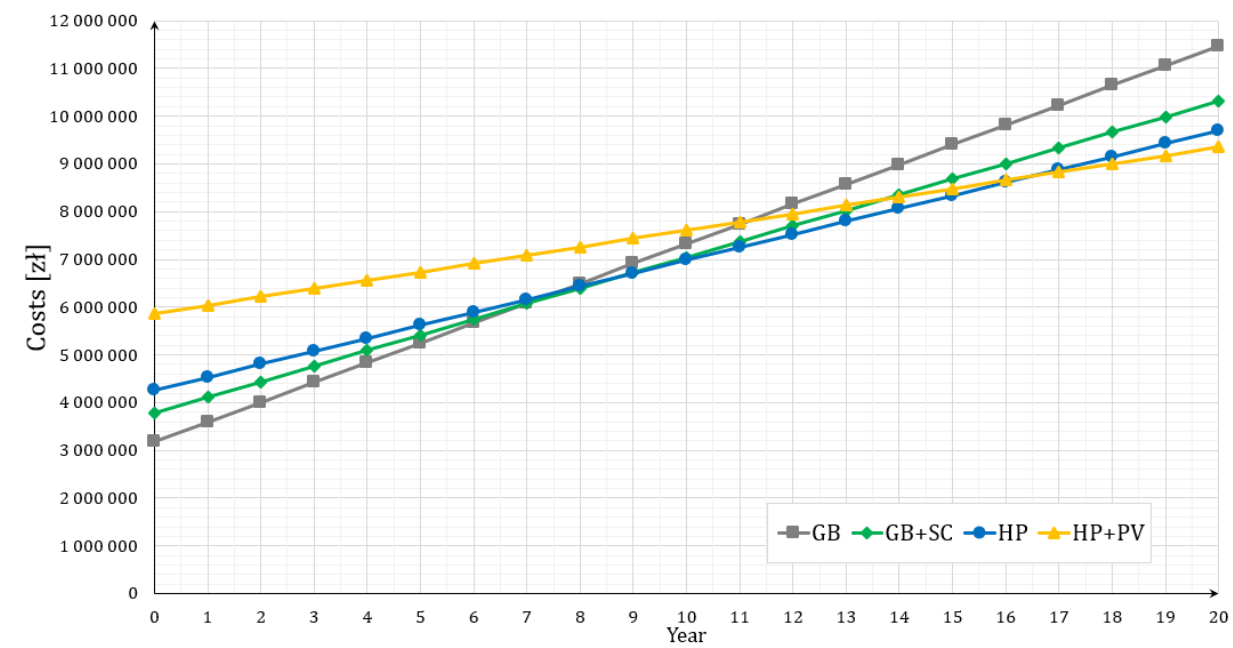

Fig. 9. Cumulative costs for all variants in Koszalin ( $1^{\text {st }}$ climate zone). 


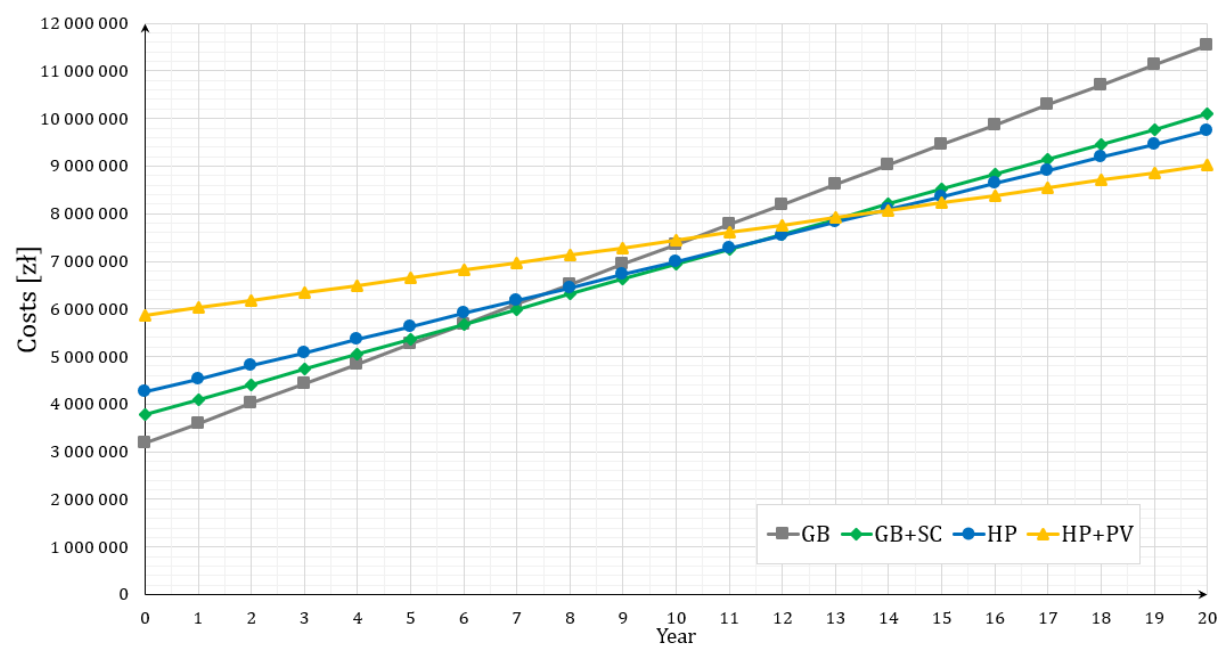

Fig. 10. Cumulative costs for all variants in Wroclaw ( $2^{\text {nd }}$ climate zone).

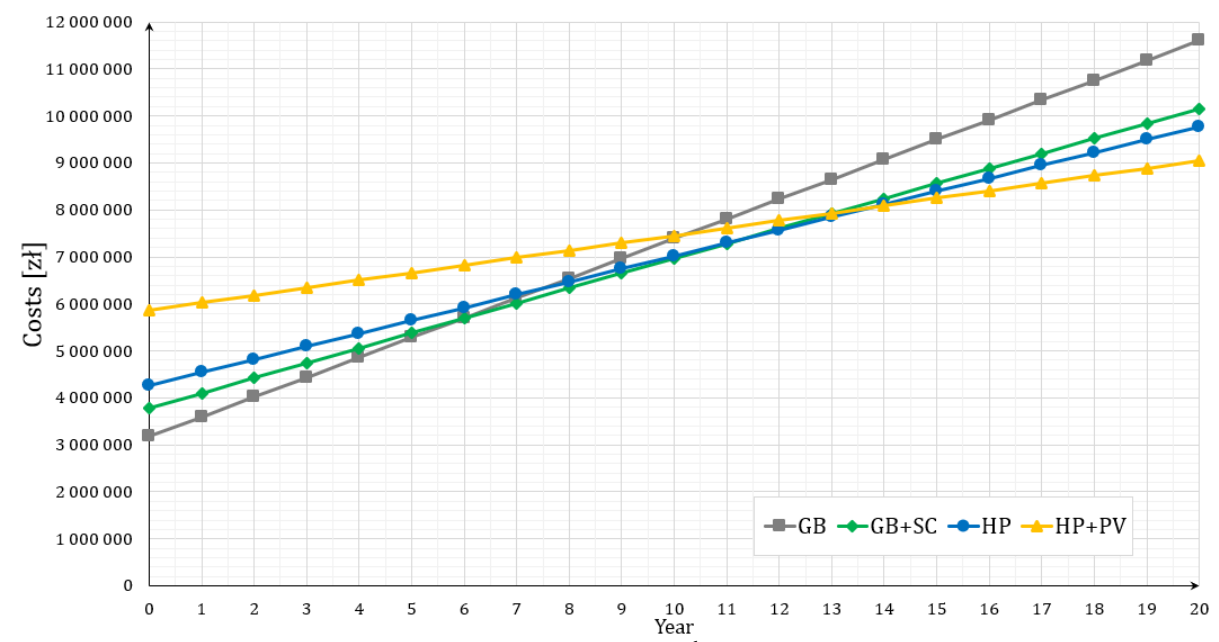

Fig. 11. Cumulative costs for all variants in Katowice ( $3^{\text {rd }}$ climate zone).

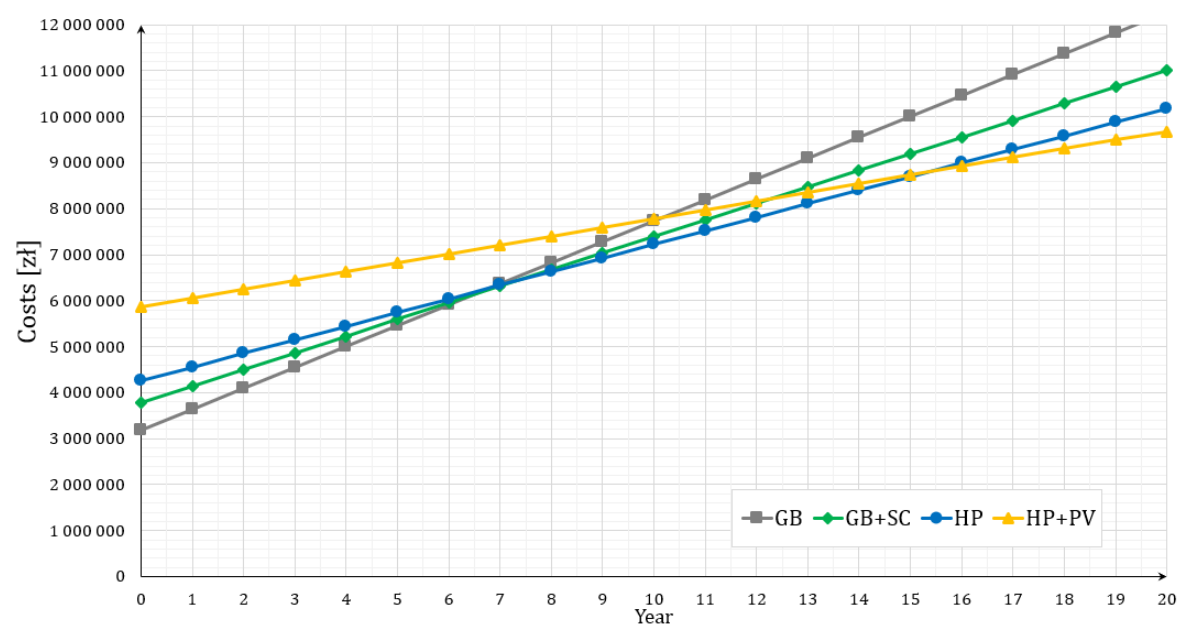

Fig. 12. Cumulative costs for all variants in Olsztyn ( $4^{\text {th }}$ climate zone). 


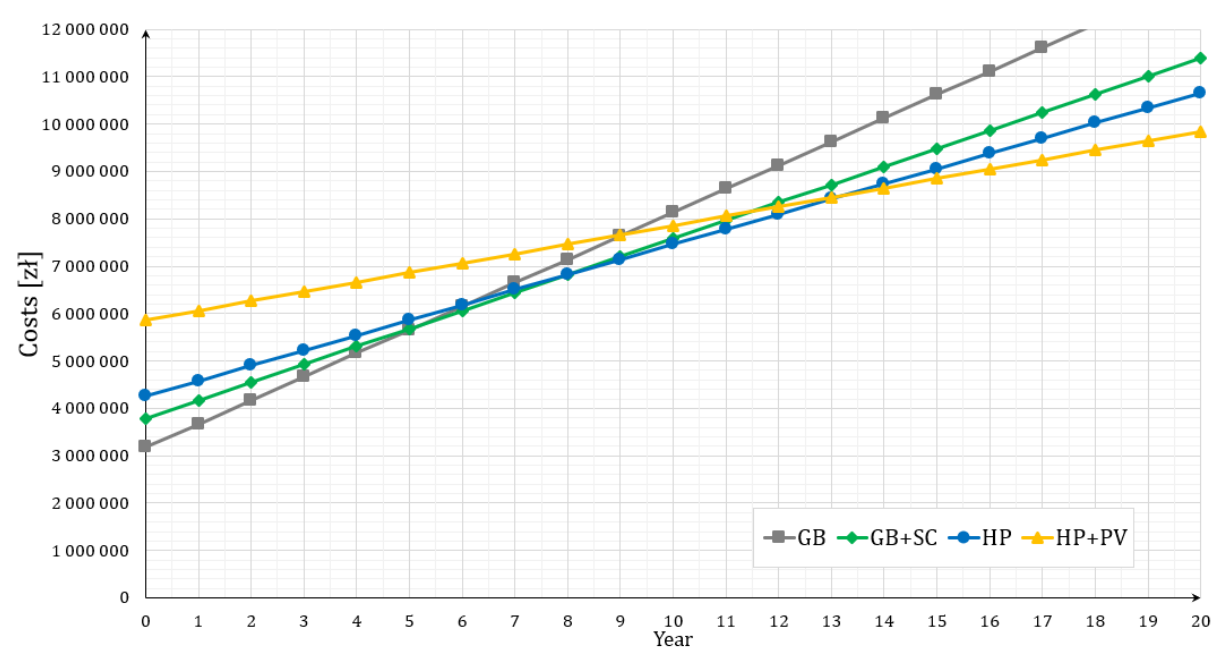

Fig. 13. Cumulative costs for all energy sources variants in Zakopane ( $5^{\text {th }}$ climate zone).

\section{Conclusions}

The calculation results have shown that basically all of Poland is suitable for air-to-water heat pumps and solar-powered energy sources. Depending on the location, the profitability of those investments are somewhat different. Because of strong solar radiation and lower outside air temperatures over the year in south of Poland the performance of renewable energy sources is the best in the most cold regions. The only exception is in the north-east part of Poland where the temperatures and solar radiations are both low. Mountain regions represented by Zakopane ( $5^{\text {th }}$ climate zone) in the analysis are likely to be the most suitable for all kinds of renewable energy sources. Cold climate in those regions forces the necessity of heating nearly all over the year, and any kind of heat source alteration for renewable sources brings financial and ecological benefits. On average, compared to other regions, all investments in Zakopane return their costs 1-2 years faster. $2^{\text {nd }}$ and $3^{\text {rd }}$ climate zones represented by Wroclaw and Katowice are both well suited for solar-powered heat and energy sources. The main reason for that is the rather stable and mild climate during most of the year and relatively high solar irradiation. In $1^{\text {st }}$ and $2^{\text {nd }}$ climate zones represented by Koszalin and Olsztyn the results are slightly different. Air-to-water heat pumps are most likely to be more profitable in those regions rather than solar-powered sources. Solar irradiation is significantly lower and temperatures are low $\left(0-10^{\circ} \mathrm{C}\right)$ most of the year. Almost all studied variants proved to be profitable and are most likely to return their costs in time shorter than 7 years. Independently from the finances all analysed renewable energy systems bring high ecological impacts in avoided emissions from about 100 tons $(25 \%)$ of $\mathrm{CO}_{2}$ for solar collectors up to 200-250 tons $(80 \%)$ of $\mathrm{CO}_{2}$ for heat pumps with photovoltaic panels.

\section{References}

1. K. Piekarska, M. Zaciera, A. Czarny, E. Zaczyńska, Environment Protection Engineering 37, 85-98 (2011)

2. K. Piekarska, Environment Protection Engineering 35, 25-35 (2009) 
3. E. Ursula, Energy efficient buildings with solar and geothermal resources (Wiley, Chichester, 2014)

4. Rynek pomp ciepła w Polsce i województwie śląskim, Park Naukowo-Techniczny Euro-Centrum, Katowice (2013)

5. M. A. Sayegh, Dissalination 209, 171-176 (2007)

6. Climate data for energy calculations for buildings, Ministry of Investments and Development, (10.04.2019r.), https://www.gov.pl/web/inwestycje-rozwoj/dane-doobliczen-energetycznych-budynkow

7. PN-B-02025:2001 - seasonal energy needs for heating

8. PN-EN 12831:2006 - space heating load

9. PN-EN ISO 6946:2008 - heat transfer of building partitions

10. PN-EN 14825:2019-03 - heat pumps calculations

11. M. A. Sayegh, N. Khayata, T. Nahhas, Energy Procedia 6, 21-28 (2011)

12. Calorific values and $\mathrm{CO}_{2}$ emission factors for year 2016, KOBiZE - The National Center for Emissions Management, Warsaw (2018)

13. J. Danielewicz, Efektywność ekonomiczna $i$ energetyczna w budownictwie jednorodzinnym (Wrocław, 2018)

14. Solar resource maps for Poland, (20.11.2018r.), https://solargis.com/products/mapsand-gis-data/free/download/poland

15. Dz. U. 2002 nr 75 poz. 690, Rozporządzenie Ministra Infrastruktury z dnia 12 kwietnia 2002 r. w sprawie warunków technicznych, jakim powinny odpowiadać budynki i ich usytuowanie 